\title{
Detecting human impacts on the flora, fauna, and summer monsoon of Pleistocene Australia
}

\author{
G. H. Miller ${ }^{1}$, J. W. Magee $^{2}$, M. L. Fogel ${ }^{3}$, and M. K. Gagan ${ }^{4}$ \\ ${ }^{1}$ INSTAAR and Geological Sciences, University of Colorado, Boulder CO 80309-0450, USA \\ ${ }^{2}$ Department of Earth and Marine Sciences, Australian National University, Canberra, ACT 0200, Australia \\ ${ }^{3}$ Geophysical Laboratory, Carnegie Inst. of Washington, 5152 Broad Branch Road, NW, Washington DC, 20015-1305, USA \\ ${ }^{4}$ Research School of Earth Sciences, Australian National University, Canberra, ACT 0200, Australia
}

Received: 7 June 2006 - Published in Clim. Past Discuss.: 18 August 2006

Revised: 22 March 2007 - Accepted: 23 April 2007 - Published: 6 August 2007

\begin{abstract}
The moisture balance across northern and central Australia is dominated by changes in the strength of the Australian Summer Monsoon. Lake-level records that record changes in monsoon strength on orbital timescales are most consistent with a Northern Hemisphere insolation control on monsoon strength, a result consistent with recent modeling studies. A weak Holocene monsoon relative to monsoon strength $65-60 \mathrm{ka}$, despite stronger forcing, suggests a changed monsoon regime after $60 \mathrm{ka}$. Shortly after $60 \mathrm{ka} \mathrm{hu}-$ mans colonized Australia and all of Australia's largest mammals became extinct. Between 60 and $40 \mathrm{ka}$ Australian climate was similar to present and not changing rapidly. Consequently, attention has turned toward plausible human mechanisms for the extinction, with proponents for over-hunting, ecosystem change, and introduced disease. To differentiate between these options we utilize isotopic tracers of diet preserved in eggshells of two large, flightless birds to track the status of ecosystems before and after human colonization. More than 800 dated eggshells of the Australian emu (Dromaius novaehollandiae), an opportunistic, dominantly herbivorous feeder, provide a 140-kyr dietary reconstruction that reveals unprecedented reduction in the bird's food resources about $50 \mathrm{ka}$, coeval in three distant regions. These data suggest a tree/shrub savannah with occasionally rich grasslands was converted abruptly to the modern desert scrub. The diet of the heavier, extinct Genyornis newtoni, derived from $>550$ dated eggshells, was more restricted than in co-existing Dromaius, implying a more specialized feeding strategy. We suggest that generalist feeders, such as Dromaius, were able to adapt to a changed vegetation regime, whereas more specialized feeders, such as Genyornis, became extinct. We speculate that ecosystem collapse across arid and semi-arid
\end{abstract}

Correspondence to: G. H. Miller

(gmiller@colorado.edu) zones was a consequence of systematic burning by early humans. We also suggest that altered climate feedbacks linked to changes in vegetation may have weakened the penetration of monsoon moisture into the continental interior, explaining the failure of the Holocene monsoon. Climate modeling suggests a vegetation shift may reduce monsoon rain in the interior by as much as $50 \%$.

\section{Introduction}

Australia was rifted from Antarctica in the early Tertiary, and since then has drifted slowly northward in isolation on the Austral-Indian plate. Before rifting, marsupials migrated from South America, across Antarctica, and on to the Australian continent, but no placental mammals made the journey. Over the subsequent $50 \mathrm{My}$, the Australian marsupial fauna evolved into unique groups of herbivores and carnivores. Prior to human colonization, the only placental mammals in Australia were bats, and a few small rodents that arrived opportunistically on flotsam from SE Asia. As the continent entered the subtropical high-pressure zone in the late Tertiary, and global climate evolved in response to the break up of Gondwanaland, the climate of Australia became more arid, with the ancient Gondwanan plants concentrated in the better-watered eastern seaboard and the southwest, and with newly evolved drought-adapted plants and animals dominating the arid and semi-arid interior.

In the present regime, the Australian Monsoon dominates the moisture balance across northern Australia where summer precipitation exceeds $1000 \mathrm{~mm}$. But precipitation totals diminish rapidly inland to less than $300 \mathrm{~mm}$ within a few hundred $\mathrm{km}$ of the coast. Only infrequently do heavy monsoon rains penetrate deep into the continental interior. A

Published by Copernicus Publications on behalf of the European Geosciences Union. 


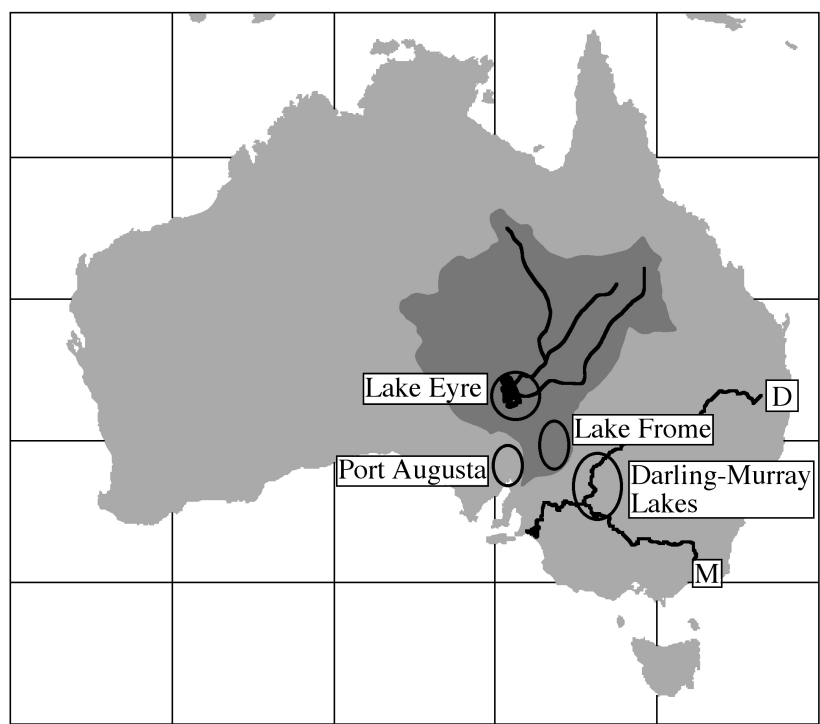

Fig. 1. Map of Australia showing the Lake Eyre Basin (dark shading) with Lake Eyre and its major fluvial systems, and generalized areas from which eggshell have been collected around Lake Eyre, Port Augusta, Lake Frome, and the Darling-Murray Lakes. The Darling (D) and Murray (M) rivers are indicated.

wide range of proxy evidence indicates that monsoon rainfall was generally strongest during global interglaciations, but weakened dramatically during global glaciations, leaving the interior both dry and cold (Nansen et al., 1992; Hesse et al., 2004; Magee et al., 2004). Even the better-watered coastal fringes witnessed the expansion of grasses at the expense of closed forest ecosystems during global glaciations (Kershaw, 1991; Kershaw et al., 2003). On orbital timescales, the planetary monsoon system is controlled by the distribution of solar insolation (Milankovitch cycles), sea surface temperatures (SST), and sea level. High SST, high sea level, and peak insolation seasonality are correlated with the penetration of monsoon rainfall deep into continental interiors (Kutzbach et al., 1998; Kutzbach and Guetter, 1986).

In this paper we argue that the primary forcing of the Australian Summer Monsoon on orbital timescales is Northern Hemisphere insolation modulated by ocean characteristic linked to global glacial/interglacial cycles. Proxy evidence is derived from Lake Eyre, an ideal rain gauge for past changes in monsoon strength. When sea level and SST are high, and Northern Hemisphere winter insolation is lowest, the Australian Monsoon is strongest. This interpretation is supported by proxy data from other dry lakes across the semi-arid zone and by recent modeling experiments. The Lake Eyre waterlevel record also leads to an enigma: it suggests that the Holocene was anomalously dry, suggesting a changed monsoon regime after $60 \mathrm{ka}$. The window of monsoon regime change overlaps with human colonization of Australia and extinction of its megafauna. Possible causes of megafaunal extinction are constrained by the dietary record preserved in eggshells of two large, flightless birds adapted to the arid and semi-arid-zones, the extant Australian emu (Dromaius novaehollandiae) and the larger and now extinct Genyornis newtoni. A nearly continuous record of dietary intake for Dromaius throughout the past $140 \mathrm{kyr}$ suggests unprecedented ecosystem disturbance 50 to $45 \mathrm{ka}$, about the same time that humans colonized the continent and most large mammals became extinct. The contrast between diets of coexisting Dromaius and Genyornis offers insights into why some large taxa became extinct, whereas others survived through to the present. Finally, we use a climate model to explore whether a change of vegetation suggested by the dietary reconstructions might have impacted the penetration of monsoon moisture into the continental interior, a link that may help explain the weak Holocene monsoon.

\section{Waterlevel changes at Lake Eyre: implications for monsoon forcing}

The Lake Eyre Basin is a large internal drainage network $\left(1.2 \times 10^{6} \mathrm{~km}^{2}\right)$ fed dominantly by a summer-monsoon rainfall catchment (Fig. 1). Lake Eyre $(15 \mathrm{mbsl})$ is the terminal playa of the Lake Eyre Basin, and its sedimentary history and paleohydrology constitute a paleorecord of monsoon runoff. In the modern climate regime, Lake Eyre only receives significant fluvial inflows during rare years when an intensified monsoon trough is displaced significantly to the south, or one or more discrete monsoon depressions, characterized by intense convection and heavy rainfall, reach into the Lake Eyre Basin. Although Lake Eyre is an ephemeral playa in the modern regime, beaches above the modern playa, deepwater lacustrine sediments found in boreholes and cliffed exposures, and fluvial aggradation in inflowing streams define intervals of perennial lacustrine conditions during the Middle and Late Quaternary. Under drier conditions, playa deepening occurs as evaporation lowers the saline water table and salt-disrupted sediment is deflated to downwind transverse dunes or lunettes, or is removed from the basin as dust. Deflation of lake sediment results in the incision of inflowing streams as they adjust to the lowered base level.

Magee et al. (2004) use these features and multiple dating techniques to derive a nearly continuous record of waterlevel changes in Lake Eyre for the past $150 \mathrm{kyr}$ (Fig. 2). Greatest effective aridity in that period occurred in MIS (marine oxygen isotope stage) 6 , when an interval of depressed groundwater allowed deflation to lower the playa surface $4.3 \mathrm{~m}$ below its current level (Magee et al., 1995; Magee and Miller, 1998). This arid event was followed abruptly by the wettest phase of the past $150 \mathrm{kyr}$, with a perennial lake stabilizing at $10 \mathrm{~m}$ a.s.l., nearly $25 \mathrm{~m}$ above the modern playa, during the last interglaciation (ca. 130 to $120 \mathrm{ka}$ ). Coeval fossil assemblages indicate diverse and abundant aquatic and terrestrial ecosystems, including now-extinct megafauna, lived in and 
around Lake Eyre (Tedford and Wells, 1990). Records signifying an enhanced Australian monsoon during the last interglaciation come from other Lake Eyre catchment fluvial sites (Croke et al., 1996; Nanson et al., 1988) and other monsoonfed lakes of northern Australia (Bowler et al., 1998; Bowler et al., 2001).

Following the peak waterlevel of MIS 5e, Lake Eyre shallowed and briefly dried at least once, but no evidence is seen of deflation or pedogenesis, before refilling again to $5 \mathrm{~m}$ a.s.l. between 100 and $75 \mathrm{ka}$. Fluctuations in lake level and salinity suggest decreasing regularity of inflow and gradual diminution of the monsoon toward the end of this wet phase. Lake sediments were pedogenically modified and eventually truncated by deflation when the lake dried at 75 to $70 \mathrm{ka}$ and disrupted gypsiferous playa sediments were transported downwind. Incision of tributary rivers into fluvial and lacustrine sediments graded to the earlier high-water phase extends almost to the modern level, documenting a transition to significant aridity and deflation. Lacustrine conditions returned 65 to $60 \mathrm{ka}$, depositing lake sediment and a prominent beach at about $3 \mathrm{~m}$ b.s.l.; coeval fluvial aggradation and vertical accretion of overbank muds occurred. This phase represents the last deep-water perennial lake and the last interval of at least moderately effective monsoon precipitation in the basin. Subsequent eolian deflation excavated the modern Lake Eyre playa, reflecting a major change in hydrological conditions from high to low water tables, rather than extreme aridity. The youngest articulated marsupial megafaunal remains found around Lake Eyre occur in lunette sediments dated to $50 \pm 5 \mathrm{ka}$ (S. T. Webb, J. W. Magee and others, unpub. OSL \& ESR dates), similar to the youngest dated Genyornis (Miller et al., 1999).

After a prolonged period of drought and irregular minor playa deflation from 35 to $14 \mathrm{ka}$, the onset of low-level, perennial, lacustrine conditions occurred by $12 \mathrm{ka}$ (Gillespie et al., 1991). The onset of wetter conditions in Lake Eyre closely follows monsoon regeneration in northwestern Australia at $14 \mathrm{ka}$ (Wyrwoll and Miller, 2001; van der Kaars and DeDeckker, 2002). Reduced inflow to Lake Eyre after 4 to $3 \mathrm{ka}$ established the modern ephemerally flooded playa regime. The absence of early Holocene beaches suggests that the lake was below the highest floods of the modern ephemeral regime (6.7 to $8.8 \mathrm{~m}$ b.s.l.; Dulhunty, 1975). The mode change to less frequent but more extreme events may reflect a change in the character of ENSO in the middle Holocene, as suggested by Rodbell et al. (1999) and Tudhope et al. (2001).

Two intriguing conclusions have been derived from the 150-kyr-waterlevel curve for Lake Eyre (Fig. 2): Northern Hemisphere insolation pacing of the Australian Monsoon, and the apparent failure of the Holocene monsoon.

The pacing of the Australian Monsoon through the Late Quaternary follows precessional Milankovitch frequencies, within the uncertainties of the dating; the key question has been whether Northern or Southern Hemisphere insolation

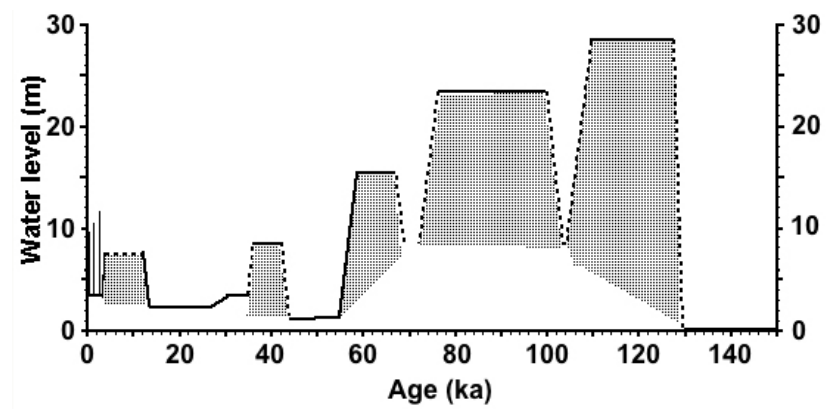

Fig. 2. Lake Eyre waterlevel curve for the past $150 \mathrm{ka}$ (modified from Magee et al., 2004). Elevations are meters above the deepest basin if all current Quaternary sediment were removed. The lake floor was last excavated to this level during the extreme aridity of MIS 6.

provides the strongest constraint. The abrupt transition from extreme aridity (characteristic of global glacial maxima) to the maximum lakelevel in the record about $130 \mathrm{ka}$ is most consistent with the MIS6/5 transition. It is similar to the well-dated MIS2/1 transition about $12 \mathrm{ka}$ from an interval of desiccation and eolian deflation to a low but permanent waterlevel in Lake Eyre. Permanent lakes during MIS 5e and the first half in MIS 1 occurred during Southern Hemisphere summer insolation minima, opposite to what would be expected in a classic monsoon setting. These intervals are also Northern Hemisphere winter insolation minima, a condition that results in intensification of the Siberian high-pressure cell, stronger outflow of air from Asia, and consequently a greater chance of displacement of the monsoon trough on to the Australian continent (Magee et al., 2004). During the second half of the Holocene, the permanent water body in Lake Eyre dried, coincident with increasing summer insolation over Australia. This relation is inconsistent with dominant forcing by summer insolation over Australia. Rather, it suggests that Northern Hemisphere insolation provides the dominant first-order forcing of the Australian Monsoon on orbital timescales.

Climate modeling of the planetary monsoons during the Holocene (Liu et al., 2003; Marshall and Lynch, 2006) also simulate a stronger Australian Monsoon during the early Holocene than at present. In contrast, the other Southern Hemisphere monsoons (Africa and South America) are stronger in the Late, rather than Early Holocene in their simulations, consistent with Southern Hemisphere insolation forcing. Both studies argue that other factors in addition to Northern Hemisphere insolation influence the strength of Australian Monsoon in their models, but the first-order changes are closely in phase with Northern Hemisphere insolation forcing, rather than direct summer insolation forcing over the Australian continent.

A second conclusion regards the height of the permanent water body in Lake Eyre during the Holocene relative to 

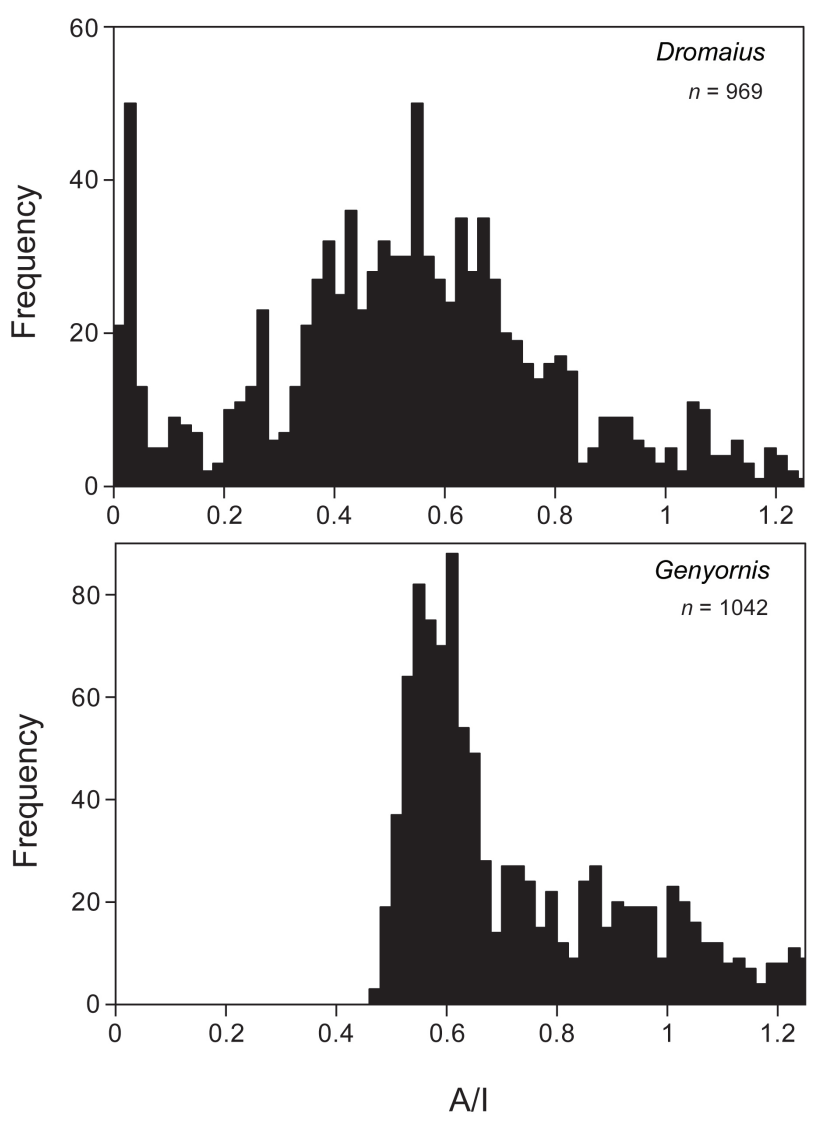

Fig. 3. Frequency histograms showing the extent of amino acid racemization (A/I) in eggshells of Genyornis and Dromaius from the Lake Eyre region over the past $150 \mathrm{ka}$. These data show the continuous presence of Dromaius and the complete disappearance of Genyornis about $50 \mathrm{ka}$. The number of samples in both datasets $(n)$ is considerably expanded from the data available to Miller et al. (1999), but the conclusions remain the same.

waterlevels in Lake Eyre 65-60 ka. The Holocene lake was substantially lower than the MIS 3 lake (Fig. 2), even though primary monsoon forcings $65-60 \mathrm{ka}$ (insolation, SST, sea level) were weaker than at any time in the Holocene. The lack of a Holocene highstand in Lake Eyre contrasts with substantial reinvigoration of the planetary monsoon in the early Holocene outside Australia (Carmouze and Lemoalle, 1983; Hoelzmann et al., 2000; Liu and Ding, 1998; Rousseau and Wu, 2000; Wasson, 1995; Williams et al., 2000) and coeval reactivation of the monsoon along the northern Australian fringe at this time (Nanson et al., 1991; Nott and Price, 1994). The failure of the Holocene monsoon evidenced by the Lake Eyre waterlevel curve was interpreted by Magee et al. (2004) to suggest that there must have been a significant boundary condition change over Australia sometime between $60 \mathrm{ka}$ and the early Holocene. An assessment of possible changes in climate and biota across central Australia over the past $60 \mathrm{kyr}$ is the focus of the remainder of this paper.

\section{Large-scale changes in Australia after $60 \mathrm{ka}$}

Australia suffered a major loss of its large- and mediumsized land mammals in the Late Quaternary. All marsupials $>100 \mathrm{~kg}$ (19 species) and 22 of 38 species between 10 and $100 \mathrm{~kg}$ became extinct (Flannery, 1990), along with three large reptiles and Genyornis newtoni (Murray and VickersRich, 2004); two other large flightless birds, the emu (Dromaius novaehollandiae) and the cassowary (Casuarius casuarius) survived. Dwarfing and range restriction occurred in many other species (Flannery, 1990). Collectively, the lost species are often referred to as the Australian megafauna, although most are of modest body mass. For more than a century the cause of this exceptional extinction has been debated without a clear consensus, largely due to the difficulty in dating faunal remains close to the limit of radiocarbon dating (Baynes, 1999). Debate about the cause of megafaunal extinction initially focused on climate change (Tate, 1879) or human predation (Owen, 1877), but more recently has included indirect consequences of human activity, particularly ecosystem change resulting from burning practices (Jones, 1969; Jones, 1973; Merrilees, 1968). Resolving the debate requires secure dates on the extinction event(s), on the arrival of humans in Australia, and on major climate and environmental changes.

Recent advances in geochronology indicate that humans had colonized Australia widely by $50 \mathrm{ka}$ (Bowler et al., 2003; Gillespie et al., 2006; Roberts et al., 1998; Roberts et al., 1990; Turney et al., 2001a). The application of new dating tools and refinements in older methods now place the extinction of the Australian megafauna to between 50 and $45 \mathrm{ka}$ (Miller et al., 1999; Roberts et al., 2001). The largest datasets of direct dates on megafaunal remains are on the eggshells of Genyornis. These include datasets from Lake Eyre, Lake Frome, Port Augusta and the Darling-Murray lakes (Fig. 1). More than 1000 dated Genyornis eggshells from around Lake Eyre show the bird's continuous presence from at least $140 \mathrm{ka}$ until about $50 \mathrm{ka}$, and its subsequent complete absence in the region (Fig. 3). Eggshells of Dromaius, which breeds in the same sand hills favored by Genyornis for breeding sites, are continuously present throughout the last $140 \mathrm{ka}$ (Fig. 3). Smaller time series for other regions of Australia have the same date for Genyornis extinction, 50 $\pm 5 \mathrm{ka}$ (Fig. 4). Lake Eyre is representative of the arid core of the continent, whereas the Darling-Murray lakes represent some of the best-watered sites in the interior, at the juncture of the monsoon-fed Darling and winter-westerly-fed Murray rivers. If climate were the primary driver of extinction, we would expect to see a retraction of the megafauna to the most favorable watering sites, where extinction dates would be later than in the arid core. The lack of any difference in the timing of extinction of Genyornis across a wide climate space suggests climate is not a likely cause of Genyornis extinction. 

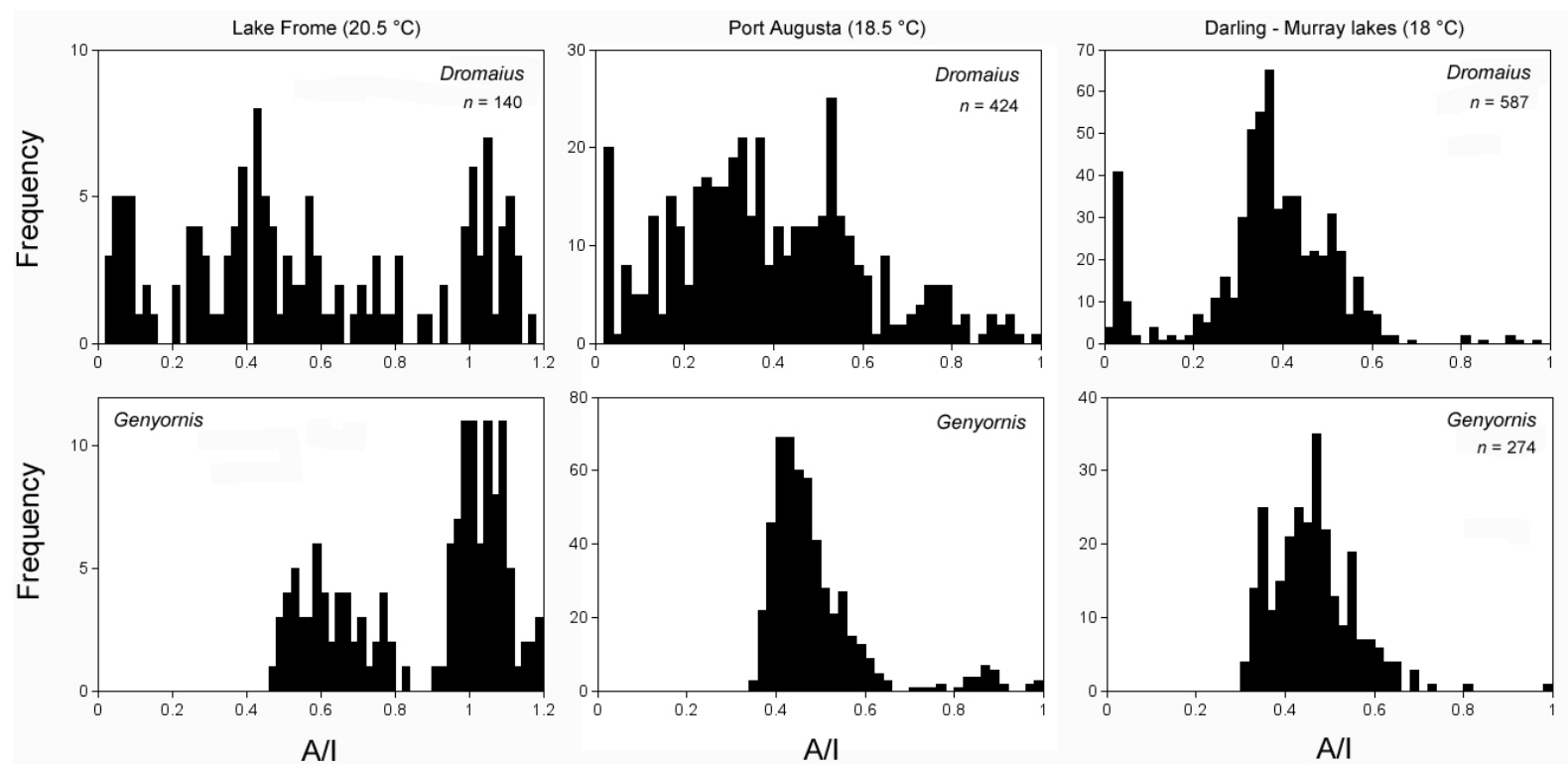

Fig. 4. Frequency histograms of A/I for Genyornis and Dromaius from collections made around Lake Frome, Port Augusta, and the DaringMurray lakes, with dates on the youngest samples derived from calibrated A/I (Miller et al., 2005a) adjusted for the current temperature differential between each region and Lake Eyre using equations in Miller et al. (2000). The actual A/I for Genyornis at extinction becomes increasingly lower at cooler sites because of the temperature-dependence of racemization rate. Earlier versions of these graphs with fewer analyses are in Miller et al. (1999).

The absence of significant climate change between 60 and $40 \mathrm{ka}$ (Hesse et al., 2004; Kershaw et al., 2003; Magee et al., 2004) and recent studies demonstrating that marsupials were well adapted to aridity and to changing climate (Prideaux et al., 2007a, b) has focused attention on plausible human mechanisms for megafaunal extinction. Given Australia's long isolation from any large placental mammals, and the capability of humans to modify landscapes even with relatively low-technology tool-kits, it seems appropriate to ask whether human colonization of the continent might had resulted in unprecedented changes to the flora and/or fauna of Australia. In addition to ecosystem modification (Jones, 1969; Merrilees, 1968; Miller et al., 1999), over-hunting (Flannery, 1994) and introduced diseases (MacPhee and Marx, 1997) have been suggested as plausible human mechanisms. To differentiate between these and other potential explanations we have sought to reconstruct the diets of Genyornis and Dromaius before and after human colonization.

\section{Paleodietary reconstructions}

Of the 60 Australian taxa known to have gone extinct in the Late Pleistocene, both size and feeding strategy have some predictive potential (Johnson and Prideaux, 2004). Most of the extinct taxa were large browsers, whereas large grazing forms, such as red and gray kangaroos, as well as many smaller browsers were less impacted. The selective loss of large browse-dependent taxa suggests ecosystem change may have been important. Fire can be an effective agent of ecosystem change. Humans have had controlled use of fire since the Middle Quaternary. They burn landscapes for many purposes, from clearing passageways and hunting along the fire-front, to signaling distant bands and promoting growth of preferred plants. Tantalizing inferential evidence for vegetation change and burning by humans about $50 \mathrm{ka}$ is recorded by pollen changes in terrestrial (Kershaw, 1986; Turney et al., 2001b) and marine (Kershaw et al., 2003) sediment cores, but pollen is rarely preserved across the arid and semi-arid zones, hampering similar investigations across most of the country. To circumvent the lack of pollen, we rely instead on isotopic tracers of diet preserved in biominerals (Johnson et al., 1998; Koch et al., 1994) to track changes in ecosystems before and after human colonization of Australia.

Almost counter intuitively, the most abundant megafaunal remains found across arid and semi-arid Australia are eggshells of the two large, flightless birds, Genyornis and Dromaius. Bird eggshells are a calcite biomineral of exceptional preservation potential. They contain $3 \%$ organic matter, most of which is sequestered within the calcite crystals of the eggshell where it is stable in the geological environment for millions of years. We use two independent measures of the birds' dietary $\delta^{13} \mathrm{C}$; the $\delta^{13} \mathrm{C}$ in the calcite minerals that make up the eggshell structure $\left(\delta^{13} \mathrm{C}_{\text {carb }}\right)$, and the $\delta^{13} \mathrm{C}$ in the organic matrix that birds place within the calcite minerals to give the eggshell resiliency $\left({ }^{13} \mathrm{C}_{\mathrm{org}}\right)$. Carbon used by a bird in making its eggshell (organic and carbonate carbon) 


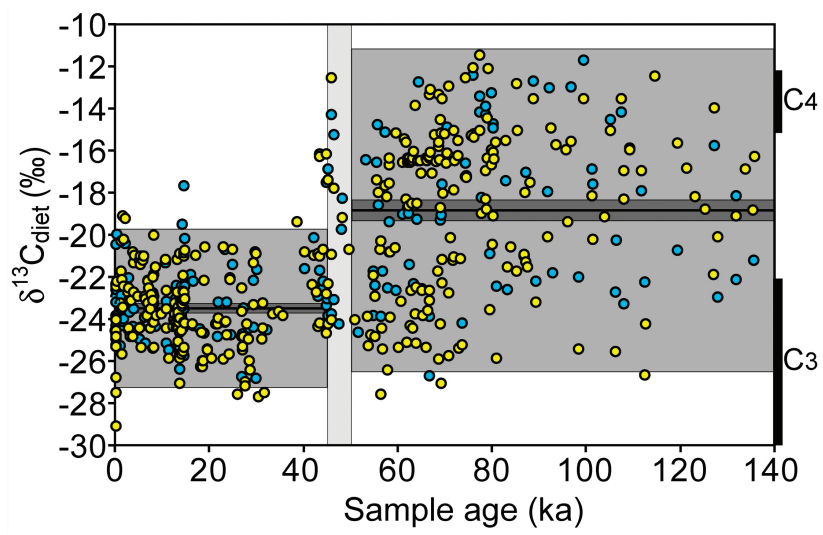

Fig. 5. 140-kyr dietary $\delta^{13} \mathrm{C}$ record for Dromaius collected around Lake Eyre, showing the dramatic change in dietary resources that occurred between 50 and $45 \mathrm{ka}$. Each sample has been independently dated. Light gray shading represents the variance, darker gray represents the standard error about the mean, and black line represents the mean $\delta^{13} \mathrm{C}$. Range of $\delta^{13} \mathrm{C}$ in modern vegetation around Lake Eyre is shown by bars on the right side of the graph. Modified from Miller et al. (2005a)

comes from the food it has eaten, offset by systematic biochemical fractionation factors (Johnson et al., 1998). Calcite carbon is derived from dissolved bicarbonate in the bloodstream, which has a relatively rapid cycle time, reflecting food sources in days to weeks before egg-laying, whereas eggshell organic carbon is derived from protein reserves that may integrate dietary intake over several months.

Our 140000-year dietary reconstruction for Dromaius from Lake Eyre is based on $\delta^{13} \mathrm{C}_{\text {org }}(n=180)$ and $\delta^{13} \mathrm{C}_{\text {carb }}$ $(n=343)$ values in individually dated eggshells (Miller et al., 2005a). Between 50 and $45 \mathrm{ka}$, mean dietary $\delta^{13} \mathrm{C}$ decreased by at least $3.3 \%$ ( $95 \%$ confidence level), accompanied by an even larger decrease in dietary variance, from 14.4 to $3.5 \%$ (Fig. 5). Prior to $50 \mathrm{ka}$, Dromaius ate a wide range of food sources, from a nearly pure $\mathrm{C} 4$ diet to a nearly pure C3 diet, with almost any combination of intermediate feeding strategies. This $\delta^{13} \mathrm{C}$ distribution is consistent with an opportunistic feeder that lived in an environment with high inter-annual moisture variability, suggesting abundant, nutritious $\mathrm{C} 4$ grasslands in wet years, and a dominance of $\mathrm{C} 3$ shrubs and trees in drier years. After $45 \mathrm{ka}$, Dromaius utilized a restricted range of food sources, dominated by $\mathrm{C} 3$ plants. The magnitude and irreversible signature of this dietary change suggests ecosystem collapse around Lake Eyre between 50 and $45 \mathrm{ka}$. We find synchronous shifts in $\delta^{13} \mathrm{C}$ of Dromaius eggshells collected from two distant regions, Port Augusta and the Darling-Murray Lakes (Fig. 6), suggesting the ecosystem change was not restricted to the core arid zone around Lake Eyre, but characterized a large portion of the arid and semi-arid zones.
Dietary reconstructions for Genyornis indicate a more specialized feeding strategy than for coexisting Dromaius; Genyornis exhibits only $40 \%$ of the isotopic variance observed in contemporary Dromaius around Lake Eyre. Genyornis diet from all three regions (Fig. 6) always includes some C4 dietary sources, unlike Dromaius, which tolerates a pure C3 diet. We conclude that Genyornis was a more specialized feeder than Dromaius, targeting a more specific set of food resources, and that these resources must have remained available through the range of climates between 140 and $50 \mathrm{ka}$.

Evidence for ecosystem change is recorded in mammals as well as avian taxa. Wombats are extant burrowing grazing marsupials that lived in the same sandhills favored by Genyornis and Dromaius as nesting sites. Preservation of their skulls is favored by sometimes dying in their burrows. Wombat skulls are occasionally found in recent sandhill exposures, where they can be dated by their association with dated eggshells. Wombats primarily eat grasses, with no known strong preference for $\mathrm{C} 3$ or $\mathrm{C} 4$ types. Consequently, changes in $\delta^{13} \mathrm{C}$ along the growth lines of their teeth reflect changing abundances of $\mathrm{C} 3$ and $\mathrm{C} 4$ grasses in their local environments (Fraser, 2006). Preliminary data on Wombat diets derived from the $\delta^{13} \mathrm{C}$ in their tooth enamel show the same patterns observed in Dromaius eggshells (Fig. 6). The greater proportion of $\mathrm{C} 4$ grass in Wombat diets prior to $50 \mathrm{ka}$ than after $45 \mathrm{ka}$, lends strong support to our interpretation of ecosystem change derived from the Dromaius dietary reconstructions.

Our eggshell and wombat tooth derived $\delta^{13} \mathrm{C}$ data provide firm evidence for an abrupt ecological shift around the time of human colonization and megafaunal extinction in Australia, between 50 and $45 \mathrm{ka}$. Climate forcing of the observed vegetation change is unlikely, given that earlier dramatic climate shifts did not result in such a large biotic response, and that climate change between 60 and $40 \mathrm{ka}$ was not large, consistent, or sustained. During this interval the Darling-Murray region experienced somewhat greater effective moisture, whereas modest drying occurred around Lake Eyre (Bowler et al., 2003; Hesse et al., 2004; Magee et al., 2004). To further test if climate could be a dominant control on the diet of the two birds, Miller et al. (2005a) subdivided the time series in Fig. 5 into $15 \mathrm{kyr}$ intervals; these include the contrasting climates of the Holocene, the last glacial maximum, and the last interglaciation. The mean and variance of each interval are not statistically different from the mean and variance of their larger groupings $(>50$ and $<45 \mathrm{ka}$ ), suggesting that climate is not the dominant control on dietary $\delta^{13} \mathrm{C}$.

We contend that a changed fire regime is a plausible mechanism for the observed ecosystem reorganization. Although Australia has a long history of burning by natural ignition, early human colonizers may have altered the timing and/or frequency of biomass burning. We hypothesize that systematic burning practiced by the earliest human colonizers may have converted a drought-adapted mosaic of trees 

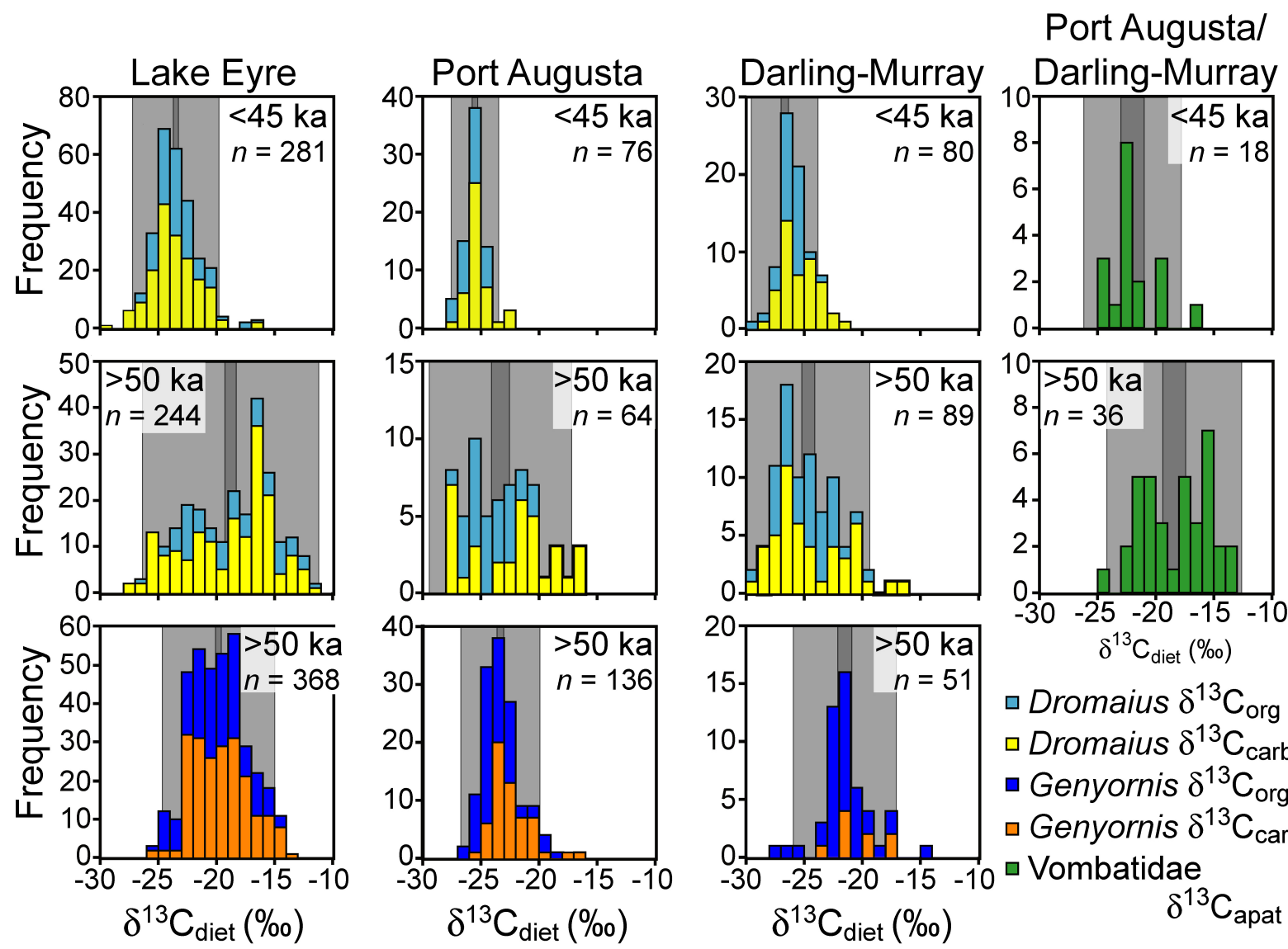

- Dromaius $\delta^{13} \mathrm{C}_{\text {org }}$

口 Dromaius $\delta^{13} \mathrm{C}_{\text {carb }}$

- Genyornis $\delta^{13} \mathrm{C}_{\text {org }}$

- Genyornis $\delta^{13} \mathrm{C}_{\text {carb }}$

$\square$ Vombatidae

$\delta^{13} \mathrm{C}_{\text {diet }}(\%)$

$\delta^{13} C_{a p a t}$

Fig. 6. Histograms of dietary $\delta^{13} \mathrm{C}$ for Dromaius and Genyornis eggshell and Wombat tooth enamel from Lake Eyre, Port Augusta and the Darling-Murray lakes contrasting the diets of animals that lived before $50 \mathrm{ka}$ with those living after $45 \mathrm{ka}$. Light gray shading represents the variance, whereas the darker gray represents the standard error about the mean $\delta^{13} \mathrm{C}$. From Miller et al. (2005a).

and shrubs intermixed with palatable nutrient-rich grasslands to the modern fire-adapted grasslands and desert scrub. Nutrient-poor soils (Barrett, 2002) would have facilitated the replacement of nutritious $\mathrm{C} 4$ grasses by spinifex, a firepromoting $\mathrm{C} 4$ grass that is well adapted to low soil nutrients, and that is largely unpalatable to most animals. A range of C3 plants may have been lost at the same time, but the isotopic dietary proxy lacks sensitivity to such a loss.

We emphasize that the dietary records (Figs. 5, 6) reflect what the birds actually ate, and are not necessarily representative of the vegetation growing in these regions. The dominance of C3 food in Dromaius diet after $45 \mathrm{ka}$ appears to be the opposite of what would be predicted if an increase in fires, as we suggest, is the cause of ecosystem change. Greater burning should promote the expansion of $\mathrm{C} 4$ grasses at the expense of other plants. In fact, this is what happened. However, $\mathrm{C} 4$ grasses in the modern landscape are dominated by spinifex and canegrass, neither of which is palatable. Hence, C4 plants do not contribute substantially to Dromaius' diet even though they dominate the landscape. Analyses of modern (1970-2000 AD) Dromaius eggshells from the Lake Eyre region show virtually no $\mathrm{C} 4$ elements in the birds' diets even though canegrass (C4) is a dominant vegetation type (Johnson et al., 2005).

\section{Human-biosphere-climate interactions}

Having established evidence for an unprecedented reorganization of vegetation across large tracts of the arid and semiarid zones, we may ask whether there is any link between the reconstructed changes in vegetation and climate, particularly the delivery of monsoon rain into the continental interior. In addition to large-scale forcing of the planetary monsoon system discussed earlier, local boundary conditions also impact the distribution of monsoon rainfall. Vegetation and soil influence the penetration of moisture into tropical regions through the recycling of water, changes in surface roughness, albedo and other phenomena (Charney, 1975; Lapenis and Shabalova, 1994). On Quaternary timescales, altered boundary conditions linked to vegetation and soil type are thought to amplify climate change across other monsoon regions (Brostrøm et al., 1998; Kutzbach et al., 1996; Zeng 


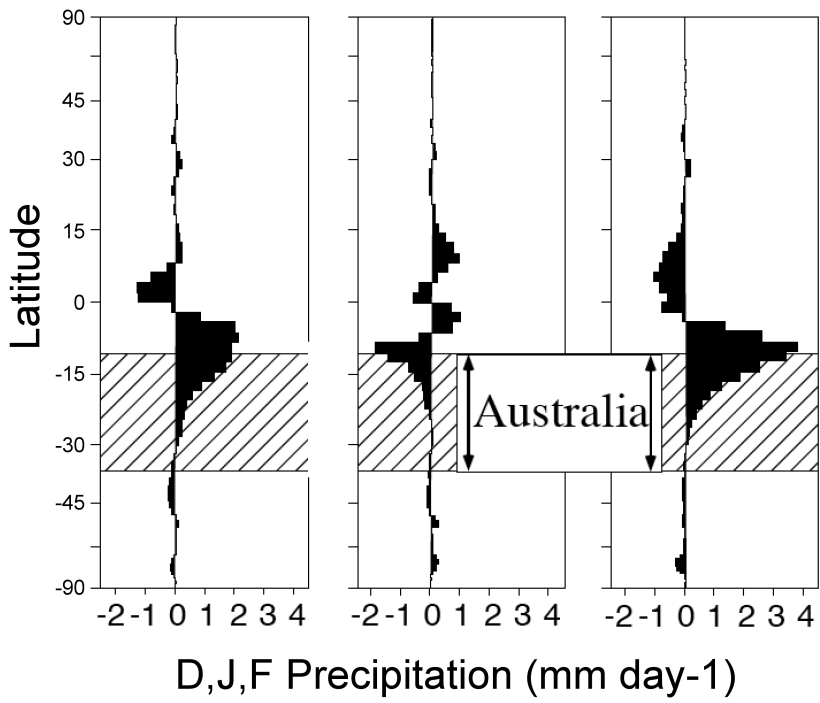

Fig. 7. Differences in simulated monsoon season (December, January, February [DJF]) precipitation along a N-S latitudinal window that encompasses Australia $\left(125-145^{\circ} \mathrm{E}\right)$ between a $10 \mathrm{ka}$ control run (interactive vegetation) and a $10 \mathrm{ka}$ simulation with Australia prescribed as forested with loamy soils (panel a), and covered by desert vegetation with sandy soils (panel b). The difference in precipitation between a vegetated and desertified Australia (panel a minus panel b) is shown in panel c. Details of the climate modeling are presented in Miller et al. (2005b).

et al., 1999). We hypothesize that the dramatic vegetation change reconstructed from our isotopic dietary proxies may have played a role in the failure of the Holocene monsoon observed at Lake Eyre (Magee et al., 2004).

To test this hypothesis, we used a general circulation model of the atmosphere to evaluate the sensitivity of monsoon precipitation to the state of vegetation and soil across Australia (Miller et al., 2005b). Recognizing that large-scale forcing of the planetary monsoon system is not likely to be altered by human activity, we chose a $10 \mathrm{ka}$ timeslice as our control, when other climate models (Liu et al., 2003; Marshall and Lynch, 2006) as well as paleodata indicate that summer (DJF) precipitation across monsoonal Australia was above present. Intervals when regional airflow across northern Australia is from the north and the monsoon trough is close to the continent are the optimal times for local boundary conditions to influence the penetration of monsoon rainfall into the interior of Australia. We compared the differences in simulated monsoonal precipitation over Australia between a $10 \mathrm{ka}$ control run, and $10 \mathrm{ka}$ simulations when Australia is prescribed as "forested" and when it is prescribed as "desert". Significant increases in DJF precipitation occur across northern Australia when the continent is forested, whereas smaller, but significant decreases in precipitation relative to the $10 \mathrm{ka}$ control are simulated when Australia is prescribed as desert (Fig. 7). DJF precipitation is more than $3 \mathrm{~mm}$ day $^{-1}$ greater across northern Australia when the continent is forested than when it is desertified, diminishing to $0.5 \mathrm{~mm} \mathrm{day}^{-1}$ by mid continent. Over the northern Lake Eyre catchment, this amounts to an effective doubling of the average annual precipitation. Because we utilized a relatively low-resolution model, and the simulations were designed as sensitivity tests rather than simulations of specific intervals in the past, these results cannot be used as specific predictors of past monsoon rainfall amounts. However, they do confirm that vegetation and soil characteristics across monsoonal Australia play a significant role in determining the penetration of monsoon moisture in the interior. A recent effort to evaluate the influence of vegetation on monsoon rainfall with a higher resolution model (Pitman and Hesse, 2007) failed to find a substantial rainfall increase, but they specified present-day insolation, a condition that our hypothesis predicts produces weak monsoon forcing. We have explicitly argued (Miller et al., 2005b) that vegetation-climate feedbacks would only be effective when boundary conditions (SST, sea level and insolation) favored strong monsoon flow. In the Holocene these conditions peaked $11 \mathrm{ka}$ and are currently at their weakest level. Consequently, the lack of a strong precipitation response reported by Pitman and Hesse (2007) is not surprising, and is, in fact, consistent with our hypothesis.

\section{Summary and conclusions}

The geologic evidence from Lake Eyre indicates that a weak but regular monsoon operated during the early Holocene, whereas the late Holocene is characterized by reduced monsoonal precipitation (Magee et al., 2004). The paleodata is consistent with Northern Hemisphere forcing of the Australian Summer Monsoon and with General Circulation Model experiments aimed at evaluating controls on the planetary monsoon systems during the Holocene (Liu et al., 2003; Marshall and Lynch, 2006). At no time in the Holocene did the Lake Eyre Basin receive sufficient monsoon rain to establish a permanent deep-water lake in Lake Eyre similar to the lakes that existed for long periods between 130 and $75 \mathrm{ka}$, despite similar forcing. The failure of the Holocene monsoon is even more pronounced by in its contrast with the permanent deep-water lake in Lake Eyre 65 to $60 \mathrm{ka}$ ago, even though insolation, sea level and SST were then less favorable for strong monsoonal flow than at any time in the Holocene. The failure of the Holocene monsoon, despite reinvigoration of the rest of the planetary monsoon system in the early Holocene, has been an enigma.

Dietary reconstructions for Dromaius and Genyornis, coupled with our climate modeling sensitivity tests, offers a plausible explanation for this enigma. The dramatic reduction in dietary intake exhibited by our isotopic data from Dromaius eggshells collected from sites across arid and semiarid Australia indicates a rapid, unprecedented, and irreversible reduction in the food resources available to this 
generalist feeder between 50 and $45 \mathrm{ka}$. A smaller time series of dietary reconstructions for the wombat, a marsupial grazer, show a similar retraction of dietary resources at the same time. Together these datasets suggest a dramatic upheaval at the base of the food chain, with the permanent conversion of a tree/shrub savannah landscape, with common years of exceptionally rich grasslands prior to $50 \mathrm{ka}$, to the modern impoverished desert scrub by $45 \mathrm{ka}$, dominated by unpalatable fire-promoting spinifex and canegrass. Dromaius, a generalist feeder, was able to adjust its feeding strategies to the changed ecosystem, whereas Genyornis, and presumably other specialized feeders, were not.

The observed ecosystem change may have had strong feedbacks on the climate system, particularly the penetration of monsoon moisture into the interior of Australia. Although our climate modeling work was necessarily at a relatively low resolution, it suggests that when forcing for the Australian Summer Monsoon is at its strongest (high sea levels, warm oceans, and strong high pressure over Asia in boreal winter), the status of vegetation and soil type across Australia may strongly influence how deeply monsoon rains penetrate into the continental interior. The reduction in surface roughness, changed albedo, reduced recycling of rainfall by evapotranspiration, and more rapid runoff, all of which would accompany a transition from a treed-savannah to the modern desert scrubland, may have resulted in a significant weakening of monsoon rain over the Lake Eyre Basin, and even as far south as Port Augusta and the Darling-Murray Lakes throughout the Holocene, relative to conditions during MIS 5 and MIS 3. Much higher resolution climate modeling is currently underway to better test this conclusion.

Although our datasets document an unprecedented ecosystem change between about 50 and $45 \mathrm{ka}$, they offer little direct evidence for what caused the observed changes. We have speculated that systematic burning by the earliest human colonizers could have changed the fire regime sufficiently across the arid and semi-arid zones, where nutrients are the lowest of any continental region (Barrett, 2002), to disrupt the pre-existing landscape (Johnson et al., 1999; Miller et al., 1999; Miller et al., 2005a, b). Our results, coupled with circumstantial evidence for extensive burning by early human colonizers (Kershaw, 1986; Kershaw et al., 2003; Turney et al., 2001b), suggest that firing of landscapes may have rapidly converted a drought-adapted mosaic of trees, shrubs, and rich grassland to the modern fire-adapted desert scrub; animals that could adapt, survived, those that could not, became extinct. Continued burning, at least until European settlement, would have maintained the changed ecosystem. Altered biosphere-atmosphere feedbacks under the changed ecosystem may have weakened the penetration of monsoon moisture into central Australia, leading to long-term desertification of the continent.
Acknowledgements. This manuscript forms the basis of a talk presented at the PAGES Open Science Meeting in Beijing, China, August 2005. The paper summarizes collaborative research over the past 15 years by our joint US-Australian team, with generous support provided by US and Australian sources. GHM gratefully acknowledges support from the National Science Foundation's Earth System History Program (ATM-9709806, ATM-0082254, and ATM-0502632), the University of Colorado at Boulder, and the Australian National University (ANU). JWM acknowledges support for this research under the Australian Research Council's Large Research Grant funding (A00104515) and QE II Fellowship award (F00103660). The Department of Earth and Marine Sciences and the Research School of Earth Sciences, ANU, provided essential logistical support. Specific details of the concepts presented here can be found in recently published papers (Miller et al., 1997; Magee and Miller, 1998; Miller et al., 1999; Johnson et al., 1999; Magee et al., 2004; Miller et al., 2005a, b). We thank station owners and managers across central Australia for access to sites, and for generous advice on travel conditions. We thank S. Webb, J. Bowler, S. DeVogel, S. Clarke, B. Johnson, N. Spooner, M. Wooller, M. McCulloch, R. Grün, the late P. Clark, J. Chappell, R. Fraser, and $\mathrm{H}$. Scott-Gagan for contributions and lively discussions over the years. GHM acknowledges a Faculty Fellowship (2005-2006) from the University of Colorado that allowed the time to complete this manuscript, and the Research School of Earth Sciences, ANU, Canberra, for hosting him.

Edited by: Pinxian Wang

\section{References}

Barrett, D. J.: Steady state turnover time of carbon in the Australian terrestrial biosphere, Global Biogeochem. Cycles, 16, 1108, doi:10.1029/2002GB001860, 2002.

Baynes, A.: The absolutely last remake of Beau Geste: yet another review of the Australian megafaunal radiocarbon dates, in: $\mathrm{Pa}-$ pers in Vertebrate Palaeontology, Records of the Western Australian Museum, Supplement 57, edited by: Baynes, A. B. and Long, J. A., pp. 391, 1999.

Bowler, J. M., Duller, G. A. T., Perret, N., Prescott, J., and Wyrwoll, K.-H.: Hydrologic changes in monsoonal climates of the last glacial cycle: stratigraphy and luminescence dating of Lake Woods, N. T. Australia, Palaeoclimates, 3, 179-207, 1998.

Bowler, J. M., Johnston, H., Olley, J. M., Prescott, J. R., Roberts, R. G., Shawcross, W., and Spooner, N. A.: New ages for human occupation and climatic change at Lake Mungo, Australia, Nature, 421, 837-840, 2003.

Bowler, J. M., Wyrwoll, K.-H., and Lu, Y.: Variations of the northwest Australian summer monsoon over the last 300,000 years: the palaeohydrologic record of the Gregory (Mulan) Lakes system, Quatern. Int., 83-85, 63-80, 2001.

Brostrøm, A., Coe, M., Harrison, S. P., Gallimore, R., Kutzbach, J. E., Foley, J., Prentice, I. C., and Behling, P.: Land surface feedbacks and paleomonsoons in northern Africa, Geophys. Res. Lett., 25, 3615-3618, 1998.

Carmouze, J.-P. and Lemoalle, J.: The lacustrine environment and its evolution, in: Lake Chad, edited by: Carmouze, J.-P., Durand, J.-R., and Lévêque, C., Dr. W. Junk Publishers, The Hague, pp. 27-64, 1983. 
Charney, J. G.: Dynamics of deserts and drought in the Sahel, Q. J. Roy. Meteor. Soc., 101, 193-202, 1975.

Croke, J. C., Magee, J. W., and Price, D. M.: Major episodes of Quaternary activity in the Neales River, north west Lake Eyre, central Australia, Palaeogeography, Palaeoclimatology, Palaeoecology, 124, 1-15, 1996.

Dulhunty, J. A.: Shoreline shingle terraces and prehistoric fillings of Lake Eyre, Transactions Royal Society South Australia, 99, 183-188, 1975.

Flannery, T. F.: Pleistocene faunal loss: implications of the aftershock for Australia's past and future, Archaeology in Oceania, 25, 45-67, 1990.

Flannery, T. F.: The Future Eaters, Reed Books, Melbourne, 1994.

Gillespie, R., Brook, B. W., and Baynes, A.: Short overlap of humans and megafauna in Pleistocene Australia, Alcheringa Special Issue, 1, 163-186, 2006.

Gillespie, R., Magee, J. W., Luly, J. G., Dlugokencky, E., Sparks, R. J., and Wallace, G.: AMS radiocarbon dating in the study of arid environments: examples from Lake Eyre, South Australia, Palaeogeography, Palaeoclimatology, Palaeoecology, 84, 333-338, 1991.

Hesse, P. P., Magee, J. W., and van der Kaars, S.: Late Quaternary climates of the Australian arid zone: a review, Quatern. Int., 118119, 87-102, 2004.

Hoelzmann, P., Kruse, H.-J., and Rottinger, H.: Precipitation estimates for the eastern Saharan palaeomonsoon based on a water balance model of the West Nubian Palaeolake Basin, Global Planetary Change, 26, 105-120, 2000.

Johnson, B. J., Fogel, M. L., and Miller, G. H.: Stable isotopes in modern ostrich eggshell: a calibration of paleoenvironmental applications in semi-arid regions of southern Africa, Geochimica Cosmochimica Acta, 62, 2451-2462, 1998.

Johnson, B. J., Miller, G. H., Fogel, M. L., Magee, J. W., Gagan, M. K., and Chivas, A. R.: 65000 Years of Vegetation Change in Central Australia and the Australian Summer Monsoon, Science, 284, 1150-1152, 1999.

Johnson, B. J., Miller, G. H., Magee, J. W., Gagan, M. K., Fogel, M. L., and Quay, P.: Carbon isotope evidence for an abrupt loss of grasses coincident with European settlement of Lake Eyre, South Australia, The Holocene, 15, 888-896, 2005.

Johnson, C. N. and Prideaux, G. J.: Extinctions of herbivorous mammals of the late Pleistocene of Australia in relation to their feeding ecology: No evidence for environmental change as cause of extinction, Austral Ecology, 29, 553-557, 2004.

Jones, R.: Fire-stick farming, Australian Natural History, 16, 224 228, 1969.

Jones, R.: Emerging picture of Pleistocene Australians, Nature, 246, 278-281, 1973.

Kershaw, A. P.: Climatic change and Aboriginal burning in northeast Australia during the last two glacials, Nature, 322, 47-49, 1986.

Kershaw, A. P., Baird, J. G., D’Costa, D. M., Edney, P. A., Peterson, J. A, and Strickland, K. M.: A comparison of long Quaternary pollen records from the Atherton and Western Plains volcanic provinces, Australia, Geological Society of Australia, Sydney, 1991.

Kershaw, A. P., van der Kaars, S., and Moss, P. T.: Late Quaternary Milankovitch-scale climatic change and variability and its impact on monsoonal Australasia, Mar. Geol., 201, 81-95, 2003.
Koch, P. L., Fogel, M. L., and Tuross, N.: Tracing the diets of fossil animals using stable isotopes, in: Stable isotopes in ecology and environmental science, edited by: Lajtha, K. and Michener, R. H. Blackwell Scientific, London, pp. 63-92, 1994.

Kutzbach, J., Bonan, G., Foley, J., and Harrison, S. P.: Vegetation and soil feedbacks on the response of the African monsoon to orbital forcing in the early to middle Holocene, Nature, 384, 623626, 1996.

Kutzbach, J., Gallimore, R., Harrison, S., Behling, P., Selin, R., and Laarif, F.: Climate and BIOME simulations for the last 21,000 years. Quatern. Sci. Rev., 17, 473-506, 1998.

Kutzbach, J. E. and Guetter, P. J.: The influence of changing orbital parameters and surface boundary conditions on climate simulations for the past 18,000 years, J. Atmos. Sci., 43, 1726-1759, 1986.

Lapenis, A. and Shabalova, M.: Global climate changes and moisture conditions in the intracontintental arid zones, Clim. Change, 27, 283-297, 1994.

Liu, T. and Ding, Z.: Chinese loess and the palaeomonsoon, Ann. Rev. Earth Planet. Sci., 26, 111-145, 1998.

Liu, Z., Otto-Bliesner, B., Kutzbach, J., Li, L., and Shields, C.: Coupled climate simulation of the evolution of global monsoons in the Holocene, J. Climate, 16, 2472-2490, 2003.

MacPhee, R. D. E. and Marx, P. A.: The 40,000-year plague: humans hyperdisease and first-contact extinctions, in: Natural Change and Human Impact in Madagascar, edited by: Goodman, S. and Pattersib, B., Smithsonian Institution Press, Washington, D.C., pp. 169-217, 1997.

Magee, J. W., Bowler, J. M., Miller, G. H., and Williams, D. L. G.: Stratigraphy, sedimentology, chronology and paleohydrology of Quaternary lacustrine deposits at Madigan Gulf, Lake Eyre, South Australia, Palaeogeography, Palaeoclimatology, Palaeoecology, 113, 3-42, 1995.

Magee, J. W. and Miller, G. H.: Lake Eyre palaeohydrology from 60 ka to the present: beach ridges and glacial maximum aridity, Palaeogeography, Palaeoclimatology, Palaeoecology, 144, 307329, 1998.

Magee, J. W., Miller, G. H., Spooner, N. A., and Questiaux, D.: A continuous 150,000 yr monsoon record from Lake Eyre, Australia: Insolation forcing implications and unexpected Holocene failure, Geology, 32, 885-888, 2004.

Marshall, A. G. and Lynch, A. H.: Time-slice analysis of the Australian summer monsoon during the late Quaternary using the Fast Ocean Atmosphere Model, J. Quatern. Sci., 21, 789-801, 2006.

Merrilees, D.: Man the destroyer; late Quaternary changes in the Australian marsupial fauna, Journal Royal Society Western Australia, 51, 1-24, 1968.

Miller, G. H., Magee, J. W., and Jull, A. J. T.: Low-latitude glacial cooling in the Southern Hemisphere from amino acids in emu eggshells, Nature, 385, 241-244, 1997.

Miller, G. H., Magee, J. W., Johnson, B. J., Fogel, M., Spooner, N. A., McCulloch, M. T., and Ayliffe, L. K.: Pleistocene extinction of Genyornis newtoni: human impact on Australian megafauna, Science, 283, 205-208, 1999.

Miller, G. H., Hart, C. P., Roark, E. B., and Johnson, B. J.: Isoleucine Epimerization in Eggshells of the Flightless Australian Birds, Genyornis and Dromaius, in: Perspectives in Amino Acid and Protein Geochemistry, edited by: Goodfriend, 
G. A., Collins, M. J., Fogel, M. L., Macko, S. A., and Wehmiller, J. F., Oxford University Press, N.Y., 2000.

Miller, G. H., Fogel, M. L., Magee, J. W., Gagan, M. K., Clarke, S., and Johnson, B. J.: Ecosystem collapse in Pleistocene Australia and a human role in megafaunal extinction, Science, 309, 287290, 2005a.

Miller, G. H., Mangan, J., Pollard, D., Thompson, S. L., Felzer, B. S., and Magee, J. W.: Sensitivity of the Australian Monsoon to Insolation and Vegetation: Implications for Human Impact on Continental Moisture Balance, Geology, 32, 885-888, 2005b.

Murray, P. F. and Vickers-Rich, P.: Magnificent mihirungs : the colossal flightless birds of the Australian dreamtime, Indiana University Press, Bloomington, 2004.

Nanson, G. C., Price, D. M., Short, S. A., Young, R. W., and Jones, B. G.: Comparative uranium-thorium dating and thermoluminescence dating of weathered Quaternary alluvium in the tropics of northern Australia, Quatern. Res., 35, 347-366, 1991.

Nanson, G. C., Young, R. W., Price, D. M., and Rust, B. R.: Stratigraphy, sedimentology and Late Quaternary chronology of the Channel Country of Western Queensland, in: Fluvial geomorphology of Australia, edited by: Warner, R. F., Academic Press, Sydney, pp. 151-175, 1988.

Nanson, G. C., Price, D. M. and Short, S. A.: Wetting and drying of Australia over the past $300 \mathrm{ka}$, Geology, 20, 791-794, 1992.

Nott, J. and Price, D. M.: Plunge pools and palaeoprecipitation, Geology, 22, 1047-1050, 1994.

Owen, R.: Researches on the fossil remains of the extinct mammals of Australia, Erxleben, London, 1877.

Pitman, A. J. and Hesse, P. P.: The significance of large-scale land cover change on the Australian palaeomonsoon, Quatern. Sci. Rev., 26, 189-200, 2007.

Prideaux, G. J., Long, J. A., Ayliffe, L. K., Hellstrom, J. C., Pillans, B., Boles, W. E., Hutchinson, M. N., Roberts, R. G., Cupper, M. L., Arnold, L. J., Devine, P. D., and Warburton, N. M.: An aridadapted middle Pleistocene vertebrate fauna from south-central Australia, Nature, 445, 422-425, 2007a.

Prideaux, G. J., Roberts, R. G., Megirian, D., Westaway, K. E., Hellstrom, J. C., and Olley, J. M.: Mammalian responses to Pleistocene climate change in southeastern Australia, Geology, 35, 33-36, 2007b.

Roberts, R., Bird, M., Olley, J., Galbraith, R., Lawson, E., Laslett, G., Yoshida, H., Jones, R., Fullagar, R., Jacobsen, G., and Hua, Q.: Optical and radiocarbon dating at Jinmium rock shelter in Northern Australia, Nature, 393, 358-362, 1998.

Roberts, R. G., Flannery, T. F., Ayliffe, L. K., Yoshida, H., Olley, J. M., Prideaux, G. J., Laslett, G. M., Baynes, A., Smith, M. A., Jones, R., and Smith, B. L.: New ages for the last Australian Megafauna: Continent-wide extinction about 46,000 years ago, Science, 292, 1888-1892, 2001.
Roberts, R. G., Jones, R., and Smith, M. A.: Thermoluminescence dating of a 50,000-year-old human occupation site in northern Australia, Nature, 345, 153-156, 1990.

Rodbell, D. T., Seltzer, G. O., Anderson, D. M., Abbott, M. B., Enfield, D. B., and Newman, J. H.: An 15,000-year record of El Nino-driven alluviation in southwestern Ecuador, Science, 283, 516-520, 1999.

Rousseau, D.-D. and Wu, N. G. Z.: The terrestrial mollusks as new indices of the Asian paleomonsoons in the Chinese loess plateau, Global Planetary Change, 26, 2000.

Tate, R.: Anniversary address of the President, Transactions and Proceedings of the Philosophical Society of South Australia, 2, xiii-lxxv, 1879.

Tedford, R. H. and Wells, R. T.: Pleistocene deposits and fossil vertebrates from the "Dead Heart of Australia", Memoirs of the Queensland Museum, 28, 263-284, 1990.

Tudhope, A. H., Chilcott, C. P., McCulloch, M. T., Cook, E. R., Chappell, J. C., Ellam, R. M., Lea, D. W., Lough, J. M., and Shimmield, G. B.: Variability in the El Niño-Southern Oscillation Through a Glacial-Interglacial Cycle, Science, 291, 1511$1517,2001$.

Turney, C. S. M., Bird, M. I., Fifield, L. K., Roberts, R. G., Smith, M. A., Dortch, C. E., Grün, R., Lawson, E., Miller, G. H., Dortch, J., Cresswell, R. G., and Ayliffe, L. K.: Breaking the radiocarbon barrier and early human occupation at Devil's Lair, southwestern Australia. Quaternary Geochronology, 55, 3-13, 2001a.

Turney, C. S. M., Kershaw, A. P., Moss, P., Bird, M. I., Fifield, L. K., Cresswell, R. G., Santos, G. M., di Tada, M. L., Hausladen, P. A., and Zhou, Y.: Redating the onset of burning at Lynch's Crater (North Queensland): Implications for human settlement in Australia, J. Quatern. Sci., 16, 767-771, 2001 b.

van der Kaars, S. and DeDeckker, P.: A Late Quaternary pollen record from deep-sea core Fr10/95, GC17 offshore Cape Range Peninsula, northwestern Western Australia, Review of Palaeobotany and Palynology, 120, 17-39, 2002.

Wasson, R. J.: The Asian monsoon during the Late Quaternary: a test of orbital forcing and palaeoanalogue forecasting, in: Memoir 32, Geological Society of India, Bangalore, pp. 22-35, 1995.

Williams, M. A. J., Adamson, D., Cock, B., and McEvedy, R.: Late Quaternary environments in the White Nile region, Sudan, Global Planetary Change, 26, 305-316, 2000.

Wyrwoll, K. H. and Miller, G. H.: Initiation of the Australian Summer Monsoon 14,000 years ago, Quatern. Int., 83-85, 119-128, 2001.

Zeng, N., Neelin, D., Lau, K.-M., and Tucker, C. J.: Enhancement of interdecadal climate variability in the Sahel by vegetation interaction, Science, 286, 1537-1540, 1999. 